\title{
First Report of Cotton Leafroll Dwarf Virus in Louisiana
}

\author{
Trey Price, ${ }^{1,+}$ Rodrigo Valverde, ${ }^{2}$ Raghuwinder Singh, ${ }^{2}$ Jeff Davis, ${ }^{3}$ Sebe Brown, ${ }^{4}$ and Hank Jones ${ }^{5}$ \\ ${ }^{1}$ Macon Ridge Research Station, LSU AgCenter, Winnsboro, LA 71295 \\ ${ }^{2}$ Department of Plant Pathology and Crop Physiology, LSU AgCenter, Baton Rouge, LA 70803 \\ ${ }^{3}$ Department of Entomology, LSU AgCenter, Baton Rouge, LA 70803 \\ ${ }^{4}$ Dean Lee Research Station, LSU AgCenter, Alexandria, LA 71302 \\ ${ }^{5} \mathrm{RHJ}$ Ag Services, LLC, Winnsboro, LA 71295
}

Accepted for publication 8 April 2020.

Keywords: cotton, Gossypium hirsutum, cotton leafroll dwarf virus, CLRDV

During July 2019, cotton (Gossypium hirsutum [L.] Merr.) (cv. NexGen 5711), growing in Richland Parish (32.615597, -91.612049), Louisiana, exhibited symptoms that consisted of foliar chlorosis and distortion with downward and upward cupping of leaves as well as reddened veins (Fig. 1). The symptoms were similar to those described for cotton leaf roll dwarf virus (CLRDV) in Alabama (Avelar et al. 2019). These symptoms were observed approximately 2 weeks after a severe cotton aphid (Aphis gossypii Glover) infestation, which was managed with an application of sulfoxaflor. The product is sold as Transform by Corteva Agriscience and is labeled for cotton aphid control. The overall incidence of affected plants in the field was less than $1 \%$. Leaves exhibiting symptoms were collected from five symptomatic plants, placed in plastic bags within a cooler containing ice, and transported to the LSU AgCenter Plant Diagnostic Center. Leaves from asymptomatic plants were sampled and transported as well. Total RNA from PDC19552 and PDC19553 cotton samples was extracted using the Qiagen RNeasy Plant Mini Kit (Qiagen, Germantown, MD). The cDNA was synthesized as described previously using primer Pol3982R (Sharman et al. 2015) using Invitrogen SuperScript IV reverse transcription. Primers Pol3982R and CLRDV3675F were used to amplify and sequence an approximately 310-bp polymerase chain reaction (PCR) product (Sharman et al. 2015). Shoots from four symptomatic plants were grafted onto healthy cotton plants (cv. DP174RF) grown in a growth chamber. Total RNA was purified from leaves of two additional symptomatic and two asymptomatic plants using the Spectrum Plant Total RNA Kit (Sigma-Aldrich, St. Louis, MO). Reverse transcription PCR (RT-PCR) was conducted using the Access RT-PCR System (Promega, Madison, WI) and primers CLRDV3675F and Pol3982R (Sharman et al. 2015). The RT-PCR testing yielded amplicons of the expected size with RNA from symptomatic plants but not with RNA from asymptomatic plants. Two amplicons were Sanger sequenced, resulting in identical sequences (MT127413). The BLASTx analysis revealed 100\% nucleotide and amino acid sequence identity to corresponding sequences of CLRDV

\section{${ }^{\dagger}$ Corresponding author: T. Price; pprice@agcenter.lsu.edu}

Funding: This work was funded by Cotton Incorporated, Louisiana State Support Committee (GR-00006333).

The author(s) declare no conflict of interest.

(C) 2020 The American Phytopathological Society
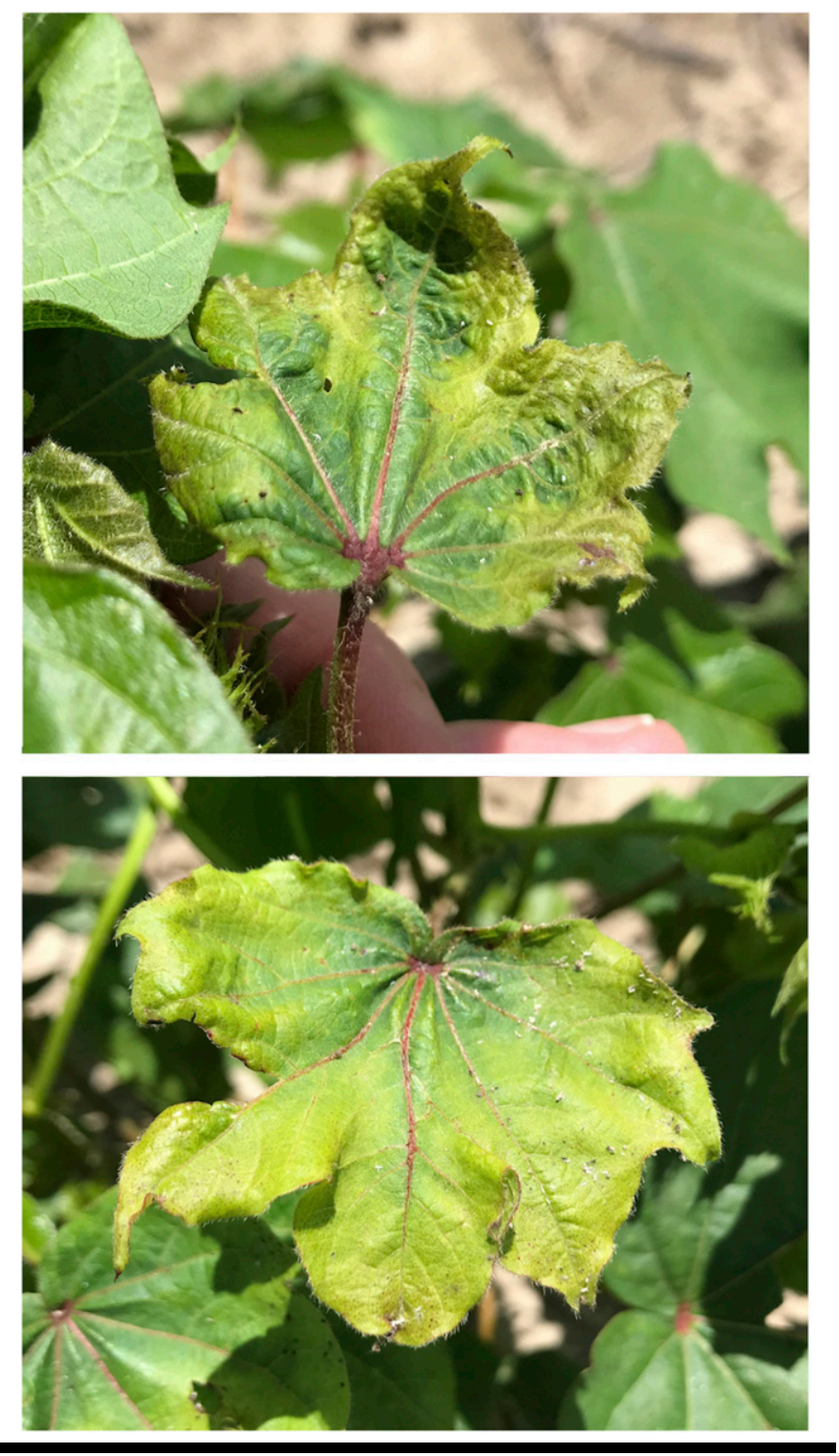

FIGURE 1

Foliar symptoms of chlorosis and distortion with upward and downward cupping as well as reddened veins by cotton plants testing positive for cotton leafroll dwarf virus during 2019 in Richland Parish, Louisiana. 


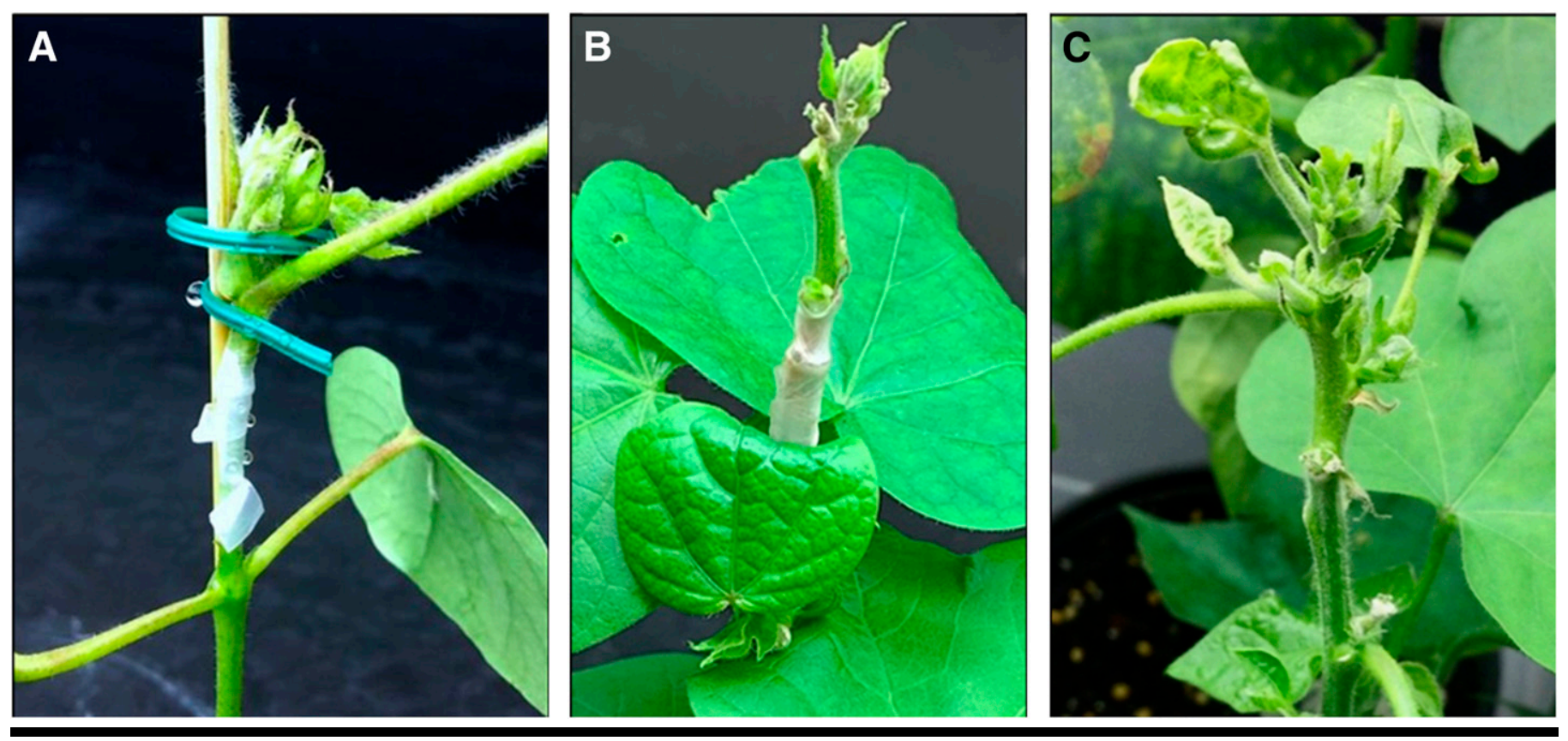

FIGURE 2

Cotton grafted with scions from field-collected plants showing foliar chlorosis and distortion with downward and upward cupping of the leaves: A, 1 week; B, 3 weeks; and $\mathbf{C}$, 8 weeks after grafting.

reported in Georgia (MK722190, QEE94781) and Alabama (MN071395, QEU57992). Some grafted plants developed mild leaf malformation 3 to 4 weeks after grafting. Severe dwarfing, leaf malformation, and upward cupping developed 6 to 8 weeks after grafting (Fig. 2). Graft transmission of CLRDV was confirmed with RT-PCR testing. CLRDV has been reported in Alabama, Georgia, Kansas, Mississippi, and Texas (Aboughanem-Sabanadzovic et al. 2019; Alabi et al. 2019; Ali and Mokhtari 2019; Avelar et al. 2019; Tabassum et al. 2019); therefore, it is not surprising that the virus also is present in Louisiana. In Louisiana during 2019, cotton was grown over 280,000 acres for a total gross farm value in excess of \$173.2 million (United States Department of Agriculture, National Agricultural Statistics Service 2019). Because of low incidence, the virus did not appear to cause significant yield losses in Louisiana during the 2019 season, although aphid pressure was higher than normal. To our knowledge, this is the first report of CLRDV occurring in Louisiana.

\section{Acknowledgments}

We thank Dr. Kassie Conner, Auburn University for providing a cDNA sample of CLRDV used as positive control in RT-PCR testing. Additionally, thanks are extended to Louisiana cotton farmers.

\section{Literature Cited}

Aboughanem-Sabanadzovic, N., Allen, T. W., Wilkerson, T. H., Conner, K. N., Sikora, E. J., Nichols, R. L., and Sabanadzovic, S. 2019. First report of cotton leafroll dwarf virus in upland cotton (Gossypium hirsutum) in Mississippi. Plant Dis. 103:1798.

Alabi, O. J., Isakeit, T., Vaughn, R., Stelly, D., Conner, K., Gaytan, B., Villegas, C., Hitzelberger, C., De Santiago, L., Monclova-Santana, C., and Brown, J. K. 2019. First report of cotton leafroll dwarf virus infecting upland cotton (Gossypium hirsutum L.) in Texas. Plant Dis. 104:998.

Ali, A., and Mokhtari, S. 2019. First report of cotton leafroll dwarf virus infecting cotton in Kansas. Plant Dis. https://doi.org/10.1094/PDIS-12-192589-PDN.

Avelar, S., Schrimsher, D. K., Lawrence, K., and Brown, J. K. 2019. First report of cotton leafroll dwarf virus associated with cotton blue disease symptoms in Alabama. Plant Dis. 103:592.

Sharman, M., Lapbanjob, S., Sebunruang, P., Belot, J., Galbieri, R., Giband, M., and Suassuna, N. 2015. First report of cotton leafroll dwarf virus in Thailand using a species-specific PCR validated with isolates from Brazil. Australas. Plant Dis. Notes 10:24.

Tabassum, A., Bag, S., Roberts, P., Suassuna, N., Chee, P., Whitaker, J. R., Conner, K. N., Brown, J., Nichols, R. L., and Kemerait, R. C. 2019. First report of cotton leafroll dwarf virus infecting cotton in Georgia, U.S.A. Plant Dis. 103:1803.

United States Department of Agriculture, National Agricultural Statistics Service. 2019. QuickStats database. https://www.nass.usda.gov/. 